Available online at http://journal.stkip-andi-matappa.ac.id/index.php/histogram/index

Histogram : Jurnal Pendidikan Matematika 4(1), 2020, 65 - 77

\title{
PENERAPAN SIKLUS ACTIVITIES, CLASS DISCUSSION, AND EXERCISE (ACE) PADA MATA KULIAH MATEMATIKA DISKRET
}

\author{
Nurlaili \\ Institut Teknologi Telkom Purwokerto \\ * Corresponding Author. Email: nurlaili@ittelkom-pwt.ac.id \\ Received: 23 Februari 2020; Revised: 21 Maret 2020 ; Accepted: 30 Maret 2020
}

\begin{abstract}
ABSTRAK
Mata kuliah matematika diskret pada struktur kurikulum Program Studi Rekayasa Perangkat Lunak (RPL) menjadi salah satu mata kuliah dasar di tahun pertama, sehingga diperlukan suatu pendekatan yang tepat dalam proses pembelajaran. Penelitian ini bertujuan untuk mengimplementasikan pembelajaran menggunakan siklus activities, class discussion, and exercise (ACE) dalam pembelajaran matematika diskret dengan sasaran peningkatan partisipasi aktif mahasiswa. Desain penelitian menggunakan pendekatan penelitian tindakan kelas dengan model Kemmis dan Taggart yang terdiri dari empat tahapan (perencanaan, pelaksanaan, observasi, dan refeleksi) dalam dua siklus. Penelitian dilaksanakan di Program Studi RPL Institut Teknologi Telkom Purwokerto dengan subjek penelitian yaitu mahasiswa kelas RPL A sebanyak 27 orang pada tahun akademik 2018/2019. Teknik pengumpulan data melalui observasi dan tes evaluasi pembelajaran. Berdasarkan hasil penelitian, penerapan siklus ACE memberikan peningkatan pada hasil pencapaian pembelajaran mahasiswa. Pencapaian aktivitas pembelajaran mahasiswa mengalami peningkatan dari 44,45\% pada siklus 1 menjadi 75,94\% pada siklus 2. Selain itu juga terjadi peningkatan hasil belajar mahasiswa dilihat dari rata-rata klasikal siklus 1 yaitu 55,8 dan siklus 2 yaitu 72,7. Hal ini menggambarkan bahwa penerapan siklus ACE dalam pembelajaran matematika diskret dapat meningkatkan capaian pembelajaran mata kuliah di kelas RPLA.
\end{abstract}

Kata Kunci: siklus ACE, aktivitas, matematika diskret

\section{ABSTRACT}

The discrete mathematics subject in the curriculum of the Rekayasa Perangkat Lunak (RPL) Departemen is the fundamental subjects for the freshman, so it have to bring in a attractive approach of learning process. The aim of this study is to implement the activities, class discussion, and exercise (ACE) cycle for the discrete mathematics learning. This implementation is designed to construct the student participation in the class. The research design uses the Kemmis and Taggart classroom action research approach including two cycles that each cycles is consists of four stages (planning, implementation, observation, and reflection). The research was conducted in the RPL Departement of the Institut Teknologi Telkom Purwokerto with 27 RPL A class students in the academic year 2018/2019 as research subject. The techniques of data collection use class observations and tests. Based on the results, the ACE cycle implementation brings an increasing in the student learning achievement. The achievement of student learning activities has increased from $44.45 \%$ in cycle 1 to $75.94 \%$ in cycle 2 . In addition, there was also an increase in student learning outcomes seen from the class score. The class score in the cycle 1 was 55.8 and in the cycle 2 was 72.7. This results demonstrate that the ACE cycle implementation in the learning of discrete mathematics can improve the learning outcome in class RPL A

Keywords: ACE cycle, activities, discrete mathematics

How to Cite: Nurlaili. (2020). Penerapan Siklus Activities, Class Discussion, and Exercise (ACE) pada Mata kuliah Matematika Diskret. Histogram: Jurnal Pendidikan Matematika, 4(1), 65 - 77, doi: http://dx.doi.org/10.31100/histogram.v4i1.541

Permalink/DOI: http://dx.doi.org/10.31100/histogram.v4i1.541

Copyright $\odot$ 2020, THE AUTHOR (S). This article distributed under the CC-BY-SA-license.

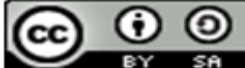




\section{PENDAHULUAN}

Pembelajaran matematika bagi mahasiswa dapat memberikan pelatihan pengembangan kemampuan berpikir kritis, sistematis, dan logis (Marta, 2017). Permasalahan yang ada dalam kehidupan sehari-hari melalui matematika dapat dibuatkan ke dalam model matematis sehingga permasalahan tersebut menjadi lebih mudah untuk diselesaikan (Safarini \& Adyan, 2019). Penerapan pembelajaran matematika dalam keilmuan teknik dan komputer menjadi salah satu komponen inti kurikulum termasuk pada program studi Rekayasa Perangkat Lunak (RPL). Dalam struktur kurikulum program studi RPL, mata kuliah matematika diskret menjadi salah satu mata kuliah dasar yang didesain untuk mahasiswa tahun pertama. Mata kuliah matematika diskret memiliki korelasi langsung dengan mata kuliah algoritma pemograman sebagai syarat pengambilan MK tersebut. Urgensi mata kuliah matematika diskret yang tinggi mendorong penulis untuk merancang sebuah pendekatan pembelajaran yang tepat agar mahasiswa dapat mengembangkan kemampuan berpikir logis, sistematis, dan logis secara optimal.

Proses pembelajaran merupakan kegiatan terencana yang dapat membuat mahasiswa belajar dengan baik. Menurut Undang-Undang No. 20 tahun 2003 Tentang Sisdiknas pasal 1 ayat 20 dalam (Rusli, Hermawan, \& Supuwiningsih, 2017) bahwa pembelajaran merupakan interaksi yang terjadi antara mahasiswa dengan dosen dan sumber belajar. Keberhasilan proses pembelajaran di kampus tidak hanya ditentukan oleh dosen yang mengajar akan tetapi peran aktif mahasiswa dalam proses pembelajaran juga sangat berpengaruh (Yustika \& Prihatnani, 2019). Berdasakan hasil wawancara yang dilakukan dengan dosen pengampu pada mata kuliah dasar tahun pertama di kelas RPL A seperti Fisika dan Kalkulus, didapatkan fakta bahwa tingkat partisipasi aktif mahasiswa dalam kegiatan pembelajaran di kelas tergolong rendah. Kondisi ini mengakibatkan pencapaian sasaran pembelajaran tidak maksimal karena mahasiswa masih malu berinteraksi di kelas apabila ada materi yang tidak dapat dipahami oleh mereka. Hal ini sejalan dengan hasil pengamatan yang dilakukan oleh Aini bahwa salah satu faktor penyebab rendahnya kemampuan mahasiswa disebabkan oleh rendahnya aktivitas mahasiswa dalam pembelajaran (Aini \& Irawati, 2018). Pada saat mengerjakan latihan hanya beberapa orang mahasiswa yang mengerjakan latihan dan mahasiswa lain lebih cendrung untuk melihat jawaban dari temannya. Berdasarkan evaluasi hasil pembelajaran pada kedua mata kuliah tersebut, ditemukan kondisi nilai akhir mahasiswa banyak yang kurang memuaskan. Hasil penelitian yang dilakukan oleh peneliti terdahulu telah 


\section{Histogram: Jurnal Pendidikan Matematika, 4(1), 2020 - 67 Nurlaili}

membuktikan bahwa peran aktif mahasiswa dalam proses pembelajaran perlu dimaksimalkan untuk memperoleh hasil belajar yang maksimal (Rahmawati, Kuswardi, \& Pambudi, 2017; Aini \& Irawati, 2018; Khamid \& Santosa, 2016).

Aktivitas belajar mahasiswa yang dimaksudkan dalam proses belajar mengajar di kampus tidak hanya terbatas pada mendengar dan mencatat apa yang disampaikan oleh dosen tetapi juga aktivitas lainnya yang dapat dilakukan oleh mahasiswa selama proses pembelajaran. Implementasi berbagai bentuk aktivitas dapat membantu mahasiswa untuk memahami materi perkuliahan lebih mudah. Paul B. Diedrich dalam (Sardiman, 2011) menggolongkan aktivitas ke dalam delapan aktivitas yaitu: 1) Visual activities seperti memperhatikan dan membaca, 2) Oral Activities seperti bertanya, memberi ide/pendapat, menanggapi, 3) Listening activities seperti mendengarkan, 4) Writing activities seperti menulis dan sebagainya, 5) Drawing activities seperti menggambar dan sebagainya, 6) Motor activities, seperti melakukan percobaan dan sebagainya, 7) Mental activities seperti mengingat, mengambil keputusan, 8) Emosional activities, seperti senang, sedih dan sebagainya. Pembelajaran matematika diskret bagi mahasiswa RPL A membutuhkan pendekatan khusus agar dapat meningkatkan partisipasi mahasiswa dan dapat meningkatkan pencapaian sasaran pembelajaran.

Berdasarkan permasalahan di atas maka diperlukan suatu pendekatan untuk dapat meningkatkan aktivitas mahasiswa. Peningkatan aktivitas belajar mahasiswa dapat dilaksanakan dalam berbagai bentuk pendekatan salah satunya menggunakan siklus Activities, Class discussion, dan Exercise (ACE). Melalui siklus ACE ini peran serta mahasiswa dalam proses pembelajaran akan dibangun karena proses pembelajaran berpusat pada mahasiswa. Asiala dkk pada tahun 1997 (Asiala et al., 1997), mengemukakan tahapan dalam proses pembelajaran melalui ACE yaitu Activities, Class discussiom dan Exercise. Tahapan pertama yaitu Activities (A) pada tahapan ini mahasiswa diminta untuk mencari materi atau mengamati permasalahan yang telah dirancang oleh dosen. Kegiatan activities ini dilakukan secara kelompok. Tujuan dari tahapan ini adalah memberikan kesempatan kepada mahasiswa untuk membangun pengetahuannya sendiri. Selain itu juga bertujuan bagi mahasiswa untuk mendapatkan pengalaman menemukan sendiri solusi dari permasalahan yang diberikan, tidak hanya menunggu jawaban dari dosen terkait permasalahan tersebut. Tahap kedua Class discussion $(C)$ dimana kegiatan yang dilakukan mahasiswa pada tahapan ini adalah berdiskusi mengenai permasalahan yang diberikan, mengemukakan pendapat mengenai materi pelajaran yang diberikan ataupun bertanya 
mengenai hal yang tidak dimengerti (Asiala et al., 1997). Dosen menjadi fasilitator selama diskusi kelas berlangsung selain itu dosen juga berfungsi untuk meluruskan konsep apabila terdapat kekeliruan (Herman, 2019). Selain itu keterlibatan dosen dalam diskusi kelas dimaksudkan untuk memberikan kesempatan kepada mahasiswa menyampaikan apa yang telah mereka kerjakan dalam kelompok (Erawati, 2018). Kegiatan ini bertujuan untuk dapat meningkatkan cara berkomunikasi antar mahasiswa. Tujuan lain dari kegiatan ini adalah dosen dapat mengetahui sejauh mana pemahaman mahasiswa terhadap materi yang diberikan. Tahap terakhir adalah Exercise (E) dimana pada tahap ini mahasiswa mengerjakan latihan dan menerapkan konsep yang telah dipelajari sebelumnya. Hal ini dapat membuat mahasiswa menjadi lebih terlatih terhadap konsep yang mereka pelajari pada saat itu (Majid, 2017).

Beberapa penelitian mengenai siklus ACE yang pernah dilakukan oleh peneliti sebelumnya membuktikan bahwa pembelajaran menggunakan siklus ACE dapat meningkatkan aktivitas dan hasil belajar. Penelitian yang dilakukan oleh Rahmawati tahun 2017 (Rahmawati et al., 2017) memperoleh hasil bahwa pembelajaran dengan menggunakan siklus ACE memberikan prestasi belajar yang lebih baik daripada siswa yang belajar tanpa siklus ACE. Berdasarkan penelitian tersebut juga diperoleh bahwa siswa yang memiliki aktivitas belajar yang tinggi prestasi belajarnya lebih baik daripada mahasiswa yang memiliki aktivitas belajar sedang maupun rendah. Penelitian lain dilakukan oleh Damaryasa tahun 2011 (Darmayasa, 2011) mendapatkan hasil bahwa melalui penerapan model pembelajaran kooperatif ACE dapat meningkatkan hasil belajar dan aktivitas mahasiswa. Hasil penelitian tersebut semakin memperkuat pemilihan pembelajaran menggunakan siklus ACE. Diharapkan melalui pembelajaran ACE dapat menfasilitasi mahasiswa untuk meningkatkan aktivitas belajar mahasiswa sehingga tujuan pembelajaran dapat tercapai secara maksimal.

\section{METODE PENELITIAN}

Jenis penelitian yang dilakukan adalah Penelitian Tindakan Kelas (PTK). Model penelitian yang digunakan adalah model spiral Kemmis dan Taggart (Wiriaatmadja, 2014). Penelitian dilaksanakan pada mahasiswa Program Studi RPL kelas A Semester 2 tahun akademik 2018/2019 dengan jumlah mahasiswa sebanyak dua puluh tujuh (27) orang. Aktivitas dan hasil belajar digunakan sebagai variabel dalam penelitian tindakan kelas ini. Penelitian dilaksanakan dalam dua siklus dengan masing-masing siklus memiliki empat 
tahapan seperti ditampilkan pada Gambar 1. Siklus penelitian dikelompokan menjadi siklus 1 dan siklus 2. Tahapan pembelajaran untuk setiap siklus dibagi menjadi 4 tahapan yaitu tahapan perencanaan (plan), tahapan tindakan (act), tahapan pengamatan (observe), dan tahapan refleksi (reflect) (Wiriaatmadja, 2014). Pada Tahapan perencanaan (plan) hal yang dipersiapkan adalah menyusun skenario pembelajaran yang dituangkan dalam rancangan proses pembelajaran (RPP), merancang lembar kerja mahasiswa (LKM), membuat indikator aktivitas yang akan diamati selama proses pembelajaran dan menyusun lembar observasi berdasarkan indikator yang telah disusun sebelumnya. Tahapan kedua setelah tahapan perencanaan selesai disusun yaitu tahapan tindakan (act). Pada tahap tindakan ini proses pembelajaran dilaksanakan sesuai dengan kegiatan yang ada pada RPP yang telah dirancang. Tahap pengamatan (observe) ini dilakukan oleh seorang observer untuk mengamati aktivitas mahasiswa selama proses pembelajaran. Tahapan terakhir dari sebuah PTK adalah tahap refleksi (reflect). Pada tahap ini kegiatan yang dilakukan adalah menganalisis hasil selama tindakan dan pengamatan untuk melihat tingkat keberhasilan atau kegagalan yang terjadi selama proses pembelajaran dalam mencapai tujuan akhir yang diharapkan. Selain itu juga untuk mengetahui apa saja kendala yang dihadapi selama PTK berlangsung pada satu siklus. Berdasarkan hasil refleksi dari siklus 1 apabila tujuan pembelajaran masih belum berhasil dicapai dan masih terdapat banyak kendala maka akan dilanjutkan pada siklus 2. Sebelum memulai siklus 2 maka dilakukan perbaikan perencanaan dari siklus 1 sehingga masalah atau kendala yang dihadapi pada siklus 1 dapat diselesaikan. Siklus ini akan berakhir apabila tujuan pembelajaran yang ingin dicapai telah sesuai dengan yang diharapkan.

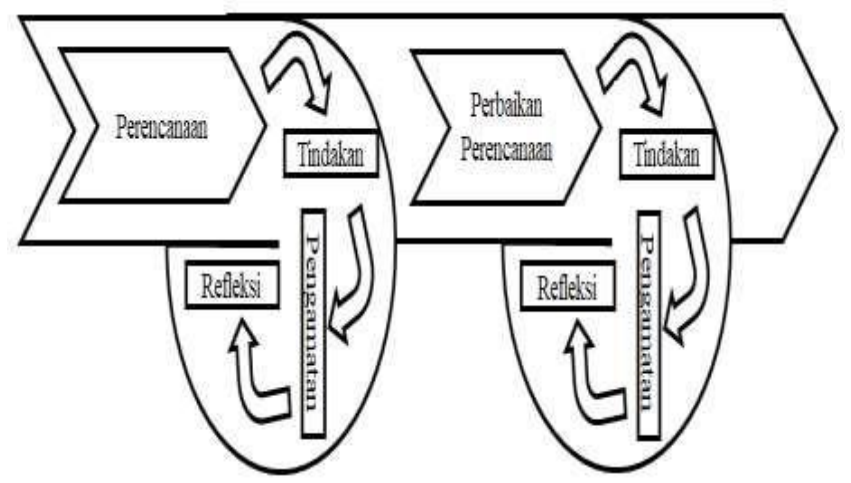

Gambar 1. Model Spiral dari Kemmis dan Taggart (Wiriaatmadja, 2014) 
Data pada penelitian ini dikumpulkan dengan menggunakan hasil wawancara dan lembar observasi. Wawancara dilakukan sebelum melakukan penelitian untuk menentukan permasalahan yang ada di kelas RPL A. Pada akhir penelitian juga dilakukan wawancara dengan mahasiswa yang bertujuan untuk mengetahui pendapat mahasiswa terhadap pembelajaran menggunakan siklus ACE. Observasi dilakukan untuk mengamati aktivitas mahasiswa selama proses pembelajaran berlangsung dengan menggunakan siklus ACE yang dilakukan oleh observer. Observer mengamati aktivitas mahasiswa ini menggunakan lembar observasi dengan memberikan tanda checklist pada kolom yang telah disediakan. Jenis aktivitas yang diamati meliputi visual activities, oral activities dan writing activities. Indikator aktivitas mahasiswa yang diamati pada penelitian ini adalah: Aktivitas 1 (AK 1): Memperhatikan penjelasan dosen/teman, Aktivitas 2 (AK 2): Membaca LKM yang diberikan, Aktivitas 3 (AK 3): Berpartisipasi dalam diskusi kelompok, Aktivitas 4 (AK 4): Mengajukan pertanyaan dan mengeluarkan pendapat atau ide pada saat diskusi kelas, dan Aktivitas 5 (AK 5) : Mengerjakan latihan yang diberikan. Analisis data untuk lembarobservasi aktivitas mahasiswa diolah menggunakan rumus

$$
P=\frac{F}{N} \times 100 \%
$$

dengan P mendefenisikan persentase aktivitas pada suatu indikator tertentu, F merupakan frekuensi mahasiswa melakukan aktivitas, dan $\mathrm{N}$ menyatakan jumlah mahasiswa.

\section{HASIL DAN PEMBAHASAN}

\section{A. Hasil Penelitian}

Penelitian tindakan kelas ini dilaksanakan dalam 2 siklus. Berdasarkan analisis data yang dilakukan terhadap lembar observasi aktivitas pada siklus 1 dan siklus 2 diperoleh hasil pada Tabel 1 .

Tabel 1. Persentase aktivitas mahasiswa per jenis aktivitas

\begin{tabular}{|c|c|c|c|c|c|c|c|c|c|}
\hline \multirow{3}{*}{$\begin{array}{c}\text { Jenis } \\
\text { Aktivitas } \\
\end{array}$} & \multirow[t]{3}{*}{ Indikator } & \multicolumn{4}{|c|}{ Siklus 1} & \multicolumn{4}{|c|}{ Siklus 2} \\
\hline & & \multicolumn{2}{|c|}{$\begin{array}{c}\text { Pertemuan } \\
\text { ke-1 }\end{array}$} & \multicolumn{2}{|c|}{ Pertemuan ke-2 } & \multicolumn{2}{|c|}{$\begin{array}{c}\text { Pertemuan } \\
\text { ke-1 }\end{array}$} & \multicolumn{2}{|c|}{ Pertemuan ke- 2} \\
\hline & & JM & $\%$ & $\mathbf{J M}$ & $\%$ & $\mathbf{J M}$ & $\%$ & $\mathbf{J M}$ & $\%$ \\
\hline \multirow{2}{*}{$\begin{array}{c}\text { Visual } \\
\text { Activities }\end{array}$} & AK1 & 14 & 51,9 & 20 & 74,1 & 24 & 88,9 & 27 & 100 \\
\hline & AK2 & 18 & 66,7 & 21 & 77,8 & 23 & 85,2 & 25 & 92,6 \\
\hline
\end{tabular}


Histogram: Jurnal Pendidikan Matematika, 4(1), $2020-71$
Nurlaili

\begin{tabular}{ccccccccccc}
\hline $\begin{array}{c}\text { Jenis } \\
\text { Aktivitas }\end{array}$ & Indikator & \multicolumn{4}{c}{ Siklus 1 } & \multicolumn{5}{c}{ Siklus 2 } \\
\hline & & \multicolumn{3}{c}{$\begin{array}{c}\text { Pertemuan } \\
\text { ke-1 }\end{array}$} & Pertemuan ke-2 & $\begin{array}{c}\text { Pertemuan } \\
\text { ke-1 }\end{array}$ & Pertemuan ke-2 \\
\hline & JM & $\%$ & JM & $\%$ & JM & $\%$ & JM & $\%$ \\
\hline $\begin{array}{c}\text { Oral } \\
\text { Activities }\end{array}$ & AK3 & 5 & 18,5 & 8 & 29,6 & 15 & 55,6 & 20 & 74,1 \\
\hline $\begin{array}{c}\text { Writing } \\
\text { Activities }\end{array}$ & AK5 & 10 & 37,0 & 15 & 55,6 & 20 & 74,1 & 24 & 88,9 \\
\hline
\end{tabular}

(Sumber: Data Primer, Tahun: 2019)

Hasil belajar dari siklus 1 dan siklus 2 dapat dilihat pada Tabel 2. Pada Tabel 2 terlihat rata-rata hasil belajar siklus 1 adalah 55,8 dan rata-rata hasil belajar siklus 2 adalah 72,7 .

Tabel 2. Hasil belajar siklus 1 dan siklus 2

\begin{tabular}{|c|c|c|c|c|c|c|}
\hline \multirow{2}{*}{$\begin{array}{c}\text { Jumlah } \\
\text { Mahasiswa } \\
\text { (orang) }\end{array}$} & \multicolumn{3}{|c|}{ Siklus 1} & \multicolumn{3}{|c|}{ Siklus 2} \\
\hline & $\begin{array}{c}\text { Nilai } \\
\text { Tertinggi }\end{array}$ & $\begin{array}{c}\text { Nilai } \\
\text { Terendah }\end{array}$ & $\begin{array}{c}\text { Nilai } \\
\text { Rata-Rata }\end{array}$ & $\begin{array}{c}\text { Nilai } \\
\text { Tertinggi }\end{array}$ & $\begin{array}{c}\text { Nilai } \\
\text { Terendah }\end{array}$ & $\begin{array}{c}\text { Nilai Rata- } \\
\text { Rata Klasikal }\end{array}$ \\
\hline 27 & 95 & 20 & 55,8 & 100 & 35 & 72,7 \\
\hline
\end{tabular}

(Sumber: Data Primer, Tahun: 2019)

1. Siklus 1

Langkah awal yang dilakukan pada tahap perencanaan (plan) adalah melakukan penelaahan terhadap RPS (Rencana Pembelajaran Semester) guna mengetahui capaian pembelajaran, materi dan alokasi waktu untuk pelaksanaann PTK. Selanjutnya disusun RPP untuk setiap kali pertemuan. Proses pembelajaran mahasiswa dibantu dengan penyusunan LKM. Langkah berikutnya adalah menentukan indikator aktivitas yang diamati selama proses pembelajaran dan membuat Lembar Observasi yang digunakan selama PTK.

Setelah tahap perencanaan selesai dilaksanakan, tahapan tindakan dilakukan di kelas dengan mengimplementasikan siklus ACE. Kegiatan dimulai dengan activities dimana mahasiswa diminta duduk dalam kelompoknya masing-masing. Pada pertemuan ke-1 suasana kelas agak sedikit ribut karena mahasiswa masih belum terbiasa belajar kelompok sehingga membutuhkan waktu yang lebih untuk mengatur tempat duduk 


\section{Histogram: Jurnal Pendidikan Matematika, 4(1), 2020 - 72 Nurlaili}

mahasiswa dalam kelompok. Selanjutnya mahasiswa diberikan LKM yang berisi permasalahan berkaitan dengan materi himpunan yang dipelajari hari itu. Dosen mengarahkan apa yang harus dilakukan oleh mahasiswa. Pada saat dosen memberikan arahan masih banyak mahasiswa yang tidak memperhatikan penjelasan dosen. Hal ini dikarenakan mahasiswa masih sibuk berbicara dengan teman satu kelompoknya walaupun sudah diperingatkan oleh dosen. Aktivitas ini dapat dilihat pada Tabel 1 dimana jumlah mahasiswa yang memperhatikan ada 14 orang, namun pada pertemuan ke-2 mengalami peningkatan sebesar 22,2\%. Pada saat dosen meminta mahasiswa untuk membaca LKM yang diberikan masih ada mahasiswa yang tidak ikut membaca LKM dan masih sibuk dengan dirinya sendiri. Pada saat diskusi dalam kelompok juga terlihat masih banyak mahasiswa yang tidak ikut berpartisipasi dalam diskusi kelompok. Berdasarkan Tabel 1 terlihat bahwa persentase mahasiswa yang terlibat secara aktif dalam kelompok (AK 3) sebesar 18,5\% dan mengalami peningkatan sebesar $11,1 \%$ pada pertemuan ke-2. Selama proses kerja kelompok dosen selalu berkeliling dan mengamati setiap pekerjaan mahasiswa.

Tahap selanjutnya setelah proses kerja kelompok selesai dilaksanakan adalah tahap Class discussion. Pada tahap ini salah satu kelompok diminta untuk menyampaikan hasil diskusi kelompok mereka di depan kelas. Namun pada pertemuan ke-1 tidak ada satupun kelompok yang berani untuk menyampaikan hasil diskusinya sehingga dosen harus menunjuk satu kelompok untuk maju. Dosen meminta kelompok yang lain untuk memberikan pendapat ataupun mengajukan pertanyaan terhadap apa yang disampaikan oleh kelompok yang tampil. Aktivitas bertanya, menanggapi dan memberikan pendapat (AK 4) pada kegiatan ini masih tergolong paling rendah. Berdasarkan Tabel 1 persentase AK 4 sebesar 11,1\% pada pertemuan ke-1 dan 22,2\% pada pertemuan ke- 2 . Hal ini dikarenakan mahasiswa masih merasa malu, takut salah dan tidak percaya diri untuk mengeluarkan pendapat ataupun mengajukan pertanyaan. Selama proses class discussion dosen selalu membimbing dan memberikan arahan agar pemahaman mahasiswa terhadap konsep materi yang dipelajari tidak keliru.

Pada tahap terakhir dari pembelajaran menggunakan siklus ACE adalah tahap Exercise dimana mahasiswa diminta untuk mengerjakan soal latihan yang telah disediakan oleh dosen di dalam LKM. Pada tahapan ini aktivitas yang diamati adalah aktivitas mengerjakan latihan. Namun masih banyak mahasiswa yang tidak mengerjakan latihan dan hanya menunggu jawaban dari temannya. Hal ini terlihat dari Tabel 1 bahwa persentase 


\section{Histogram: Jurnal Pendidikan Matematika, 4(1), 2020 - 73 \\ Nurlaili}

aktivitas mengerjakan latihan ini hanya sebesar 37\%. Namun Aktivitas ini mengalami peningkatan sebesar 18,6\% pada pertemuan ke-2.

Berdasarkan hasil dari tindakan dan pengamatan maka dilakukan refleksi untuk siklus 1 dan diperoleh hasil bahwa beberapa aktivitas sudah berjalan dengan baik seperti aktivitas membaca LKM dan memperhatikan penjelasan dosen. Pelaksanaan siklus ACE juga sudah berjalan dengan baik. Namun masih terdapat beberapa kendala (1) motivasi yang diberikan kepada mahasiswa masih kurang sehingga mahasiswa masih malu untuk bertanya dan mengeluarkan pendapat, (2) pengaturan waktu untuk diskusi masih belum tepat, (3) mahasiswa masih banyak yang tidak mengerjakan latihan karena menunggu jawaban dari temannya pada saat melaksanakan latihan. Setelah siklus 1 selesai dilaksanakan maka mahasiswa diberikan tes mengenai materi yang telah mereka pelajari dalam dua kali pertemuan. Hasil belajar mahasiswa pada siklus pertama dapat dilihat pada Tabel 2. Rata-rata nilai klasikal yang diperoleh adalah sebesar 55,8. Nilai yang paling rendah dalam tes tersebut adalah 20 .

\section{Siklus}

2

Peneliti menjadikan hasil refleksi siklus 1 sebagai acuan dalam merevisi pembelajaran pada siklus 2. Hal ini bertujuan untuk mengatasi kendala yang dihadapi pada siklus 1. Sebelum memulai siklus 2 maka dosen merevisi kembali RPP dengan memperhatikan alokasi waktu untuk diskusi kelas, sementara untuk rancangan skenario pembelajaran dalam RPP masih tetap sama dengan siklus 1. Selain itu untuk mengatasi masalah berkaitan dengan mahasiswa yang masih merasa malu untuk bertanya maka direncanakan pada pertemuan berikutnya untuk memberikan poin keaktifan kepada mahasiswa yang mau menyampaikan pendapat dan berpartisipasi dalam diskusi. Pada tahap tindakan di siklus 2 keadaan kelas sudah mulai kondusif karena mhasiswa sudah mulai terbiasa duduk dan bekerja dalam kelompok. Hal ini terlihat dari Tabel 1 dimana aktivitas memperhatikan penjelasan dosen sudah mencapai $100 \%$ pada pertemuan ke-2. Pada awal siklus 2 dosen memberikan motivasi kepada mahasiswa untuk ikut aktif dalam diskusi kelas dan dosen memberikan reward berupa point tambahan untuk keaktifan bagi mahasiswa yang mau bertanya, mengeluarkan pendapat dan memberikan tanggapan terhadap apa yang disampaikan oleh dosen dan temannya. Selama pembelajaran pada pertemuan ke-2 mahasiswa sudah mulai aktif dalam diskusi kelompok dimana mahasiswa 
sudah mulai berani bertanya kepada teman satu kelompoknya apabila ada materi yang kurang dipahami dan mahasiswa sudah mulai berani untuk menyampaikan pendapat.

Berdasarkan Tabel 1 pada siklus 2 dapat kita lihat adanya peningkatan pada aktivitas bertanya, menanggapi atau memberi pendapat dimana pada pertemuan ke-1 ada sebanyak 12 orang dan meningkat menjadi 15 orang pada pertemuan ke-2. Hal ini sangat membantu dosen untuk mengetahui seberapa jauh pemahaman mahasiswa terhadap materi yang dipelajari. Secara keseluruhan aktivitas mahasiswa mengalami peningkatan. Pada saat mahasiswa diminta untuk mengerjakan latihan hampir semua mahsiswa mengerjakan latihan, hanya 3 orang yang masih mengandalkan temannya. Namun aktivitas ini sudah mengalami peningkatan dari sebelumnya. Hasil belajar mahasiswa pada siklus 2 mengalami peningkatan yang signifikan dan memperoleh rata-rata hasil belajar klasikal sebesar 72,7. Hasil refleksi siklus 2 diperoleh bahwa proses pembelajaran menggunakan siklus ACE sudah berjalan dengan baik, aktivitas mahasiswa dalam proses pembelajaran sudah mengalami peningkatan dan hasil belajar mahasiswa juga mengalami peningkatan sehingga tujuan pembelajaran yang diharapkan sudah terpenuhi.

Tabel 3. Rata-rata aktivitas antar siklus

\begin{tabular}{ccc}
\hline Jenis aktivitas & \multicolumn{2}{c}{ Rata-rata aktivitas } \\
\cline { 2 - 3 } & \% Siklus 1 & \% Siklus 2 \\
\hline AK 1 & 63 & 94,45 \\
\hline AK 2 & 72,25 & 88,9 \\
\hline AK 3 & 24,05 & 64,85 \\
\hline AK 4 & 16,65 & 50 \\
\hline AK 5 & 46,3 & 81,5 \\
\hline Rata-rata & 44,45 & 75,94 \\
\hline
\end{tabular}

(Sumber: Data Primer, Tahun: 2019)

Berdasarkan Tabel 3 terjadi peningkatan rata-rata aktivitas dari siklus 1 dengan siklus 2 sebesar $31,49 \%$.

\section{B. Pembahasan}

Penerapan pembelajaran yang menggunakan siklus ACE dapat memberikan peningkatan terhadap aktivitas belajar mahasiswa seperti disajikan dalam hasil penelitian 


\section{Histogram: Jurnal Pendidikan Matematika, 4(1), 2020 - 75 \\ Nurlaili}

pada bagian sebelumnya. Berdasarkan nilai rata-rata persentase aktivitas untuk setiap pertemuan dalam setiap siklus mengalami peningkatan. Proses pembelajaran menggunakan siklus ACE yang berpusat kepada mahasiswa secara tidak langsung menjadikan mahasiswa untuk terlibat secara aktif dalam proses pembelajaran. Mahasisw a tidak hanya mendengarkan dan mencatat apa yang disampaikan dosen tapi mereka langsung yang mencari solusi dari permasalahan yang diberikan. Melalui kerja kelompok mahasiswa yang kurang memahami materi tersebut bisa bertanya kepada teman satu kelompok. Peningkatan aktivitas ini juga memberikan hasil yang baik terhadap hasil belajar dimana terdapat peningkatan terhadap hasil belajar mahasiswa 55,8 menjadi 72,7. Hasil penelitian ini sejalan dengan hasil penelitian yang dilakukan oleh fatmawati bahwa siklus ACE dapat meningkatkan kualitas pembelajaran dari segi motivasi, aktivitas dan prestasi belajar (Fatmawati, 2011). Penelitian lain yang dilakukan oleh Rahmawati (Rahmawati et al.,2017) juga mendukung bahwa pembelajaran menggunakan siklus ACE dapat memberikan prestasi belajar yang lebih baik.

Hasil wawancara yang dilakukan dengan beberapa orang mahasiswa diperoleh bahwa pembelajaran dengan menggunakan siklus ACE sangat menyenangkan karena mahasiswa lebih menyukai bertanya kepada temannya dari pada bertanya kepada dosen. Melalui belajar kelompok yang ada pada siklus ACE, mahasiswa tidak malu untuk mengeluarkan pendapat dan meminta bantuan kepada temannya untuk mengajarkan apa yang belum mereka pahami. Mahasiswa berpendapat bahwa pembelajaran dengan siklus ACE membuat mahasiswa tidak mengantuk selama proses pembelajaran di kelas. Hal ini dikarenakan mahasiswa terlibat secara langsung dalam menyelesaikan permasalahan yang diberikan oleh dosen. Pendapat lain y ang diperoleh dari hasil wawancara yaitu ketersediaan LKM yang diberikan kepada mereka sangat membantu untuk lebih memahami materi yang dipelajari. Berdasarkan hasil penelitian dan hasil wawancara, penulis menyatakan bahwa peningkatan aktivitas mahasiswa dari siklus 1 dan siklus 2 dapat meningkatkan hasil belajar mahasiswa.

\section{KESIMPULAN DAN SARAN}

\section{A. Kesimpulan}

Berdasarkan hasil penelitian dan bahasan dapat disimpulkan bahwa penerapan pembelajaran menggunakan siklus ACE dapat meningkatkan aktivitas belajar mahasiswa 


\section{Histogram: Jurnal Pendidikan Matematika, 4(1), 2020 - 76 \\ Nurlaili}

RPL. Rata-rata persentase aktivitas pada siklus 1 sebesar 44,45\% dan siklus 2 sebesar 75,94\%. Terjadi peningkatan sebesar 31,49\%. Penerapan pembelajaran menggunakan siklus ACE ini merupakan solusi yang tepat bagi mahasiswa RPL A untuk dapat mengatasi permasalahan yang mereka hadapi. Pembelajaran dengan menggunakan siklus ACE dapat membantu mahasiswa untuk membangun pengetahuannya sehingga dapat meningkatkan hasil belajar mahasiswa. Hal ini terlihat dari rata-rata hasil belajar mahasiswa yang meningkat dari 55,8 menjadi 72,7.

\section{B. Saran}

Penelitian ini dapat dikembangkan untuk mengetahui pengaruh dari segi motivasi, minat dan untuk melihat pengaruh pembelajaran terhadap kemampuan matematis mahasiswa.

\section{DAFTAR PUSTAKA}

Aini, S. D., \& Irawati, S. (2018). Meningkatkan Hasil Belajar Mahasiswa Melalui Pembelajaran Visual Thinking Disertai Aktivitas Quick on the Draw Improving Student Learning Outcomes through Visual Thinking Learning with Quick on the Draw Activities. 12(2), 210-219.

Asiala, M., Brown, A., DeVries, D. J., Dubinsky, E., Mathews, D., \& Thomas, K. (1997). A Framework for Research and Curriculum Development in Undergraduate Mathematics Education. -, 1-23.

Darmayasa, I. P. (2011). Pembelajaran Kooperatif Ace ( Activities , Class Discussion, Exercise ) Untuk Meningkatkan. Jurnal Pendidikan Dan Pengajaran, 44(1-3), 4451.

Erawati, N. K. (2018). Penerapan Siklus ACE APOS pada Mata Kuliah Analisis Riil. Emasains, VII(1), 22-28.

Fatmawati, A. (2011). Implementasi Siklus ACE melalui Model Pembelajaran Tipe Think Pair Share dalam Meningkatkan Kualitas Perkuliahan Pengembangan Program Pembelajaran Biologi. 1(2), 10.

Herman, Y. (2019). Peningkatan Aktivitas Dan Hasil Belajar Menggunakan Teams Games Tournament ( TGT ) Pada Pokok Bahasan Inti Atom Melalui Strategi Siklus ACE. 3(March 2018), 24-33.

Khamid, A., \& Santosa, R. H. (2016). Keefektifan pendekatan PBL dan CTL ditinjau dari komunikasi matematis dan motivasi belajar siswa SMP. PYTHAGORAS: Jurnal Pendidikan Matematika, 11(2), 111. https://doi.org/10.21831/pg.v11i2.10660

Majid, A. (2017). Strategi Pembelajaran (E. Kuswandi, ed.). Bandung: Remaja Rosdakarya.

Marta, R. (2017). Peningkatan Hasil Belajar Matematika Dengan Pendekatan Problem Solving Siswa Sekolah Dasar. Journal Cendekia:Jurnal Pendidikan Matematika,1(1), 14.

from http://journal.stkiptam.ac.id/index.php/cendekia/article/view/96/50 
Rahmawati, Y., Kuswardi, Y., \& Pambudi, D. (2017). Model, Eksperimentasi Siklus, Pembelajaran Matematika, Belajar Dari, Ditinjau Belajar, Aktivitas Xi, Kelas Ganjil, Semester. (2), 85-99.

Rusli, M., Hermawan, D., \& Supuwiningsih, N. N. (2017). Multimedia Pembelajaranan yang inovatif (1st ed.; R. Utami, ed.). Yogyakarta: ANDI.

Safarini, D., \& Adyan, F. A. (2019). Penerapan Software Geogebra pada Pembelajaran Topik lingkaran dalam Meningkatkan Hasil Belajar Siswa. Histogram: Jurnal Pendidikan Matematika, 3(2), 141-151. Retrieved from http://dx.doi.org/10.31100/histogram.v3i2.466

Sardiman, A. M. (2011). Interaksi dan Motivasi Belajar Mengajar. Jakarta: Rajawali Press. Wiriaatmadja, R. (2014). Metode Penelitian Tindakan Kelas. Bandung: Remaja Rosdakarya.

Yustika, G., \& Prihatnani, E. (2019). Peningkatan Hasil Dan Keaktifan Belajar Siswa Melalui NHT. Jurnal Cendekia: Jurnal Pendidikan Matematika, 3(2), 481-493. https://doi.org/10.31004/cendekia.v3i2.136 